\title{
Ecologically Friendly Modified Green Liquor Method for Enhancing the Technological Properties of Sugarcane Bagasse (Saccharum officinarum L.) Pulp
}

\author{
Yahia G. D. Fares, ${ }^{\mathrm{a}}$ Ayman S. Taha, ${ }^{\mathrm{b}}$ Wael A. A. Abo Elgat, ${ }^{\mathrm{c}}$ Mohamed Z. M. Salem, ${ }^{\mathrm{d}, *}$ \\ Asma A. Al-Huqail, ${ }^{e, *}$ and Hayssam M. Ali e,f
}

\begin{abstract}
Ordinary kraft pulping of bagasse was adjusted by utilizing green liquor at the laboratory and research of Misr-Edfu Pulp, Writing and Printing Paper in a small pilot batch digester (Edfu, Aswan, Egypt) as an environmentally friendly method. Bagasse pulp was produced with and without green liquor, and the physical and mechanical properties of unbleached bagasse were assessed. The parameter states of cooking were completed utilizing antacid substance charge from $10 \%$ to $13 \%$, cooking temperature from 160 to $170^{\circ} \mathrm{C}$, cooking time from 20 to $50 \mathrm{~min}$, and solid to liquor ratio of $7: 1$ that was steady in all preliminaries. The results demonstrated the exploratory idea that green liquor can provide critical pulping advantages in comparison with customary kraft pulping. Screened pulp yield improved $2.6 \%$, rejects content decreased $0.9 \%$, kappa number was reduced by $26.9 \%$, and brightness was increased by $3 \%$. There also was improved mechanical quality of bagasse pulp: increases of $14.3 \%$ (tensile index), $8.7 \%$ (tear index record), $4.6 \%$ (burst index), and 15.4\% (double fold number) were observed compared with conventional kraft pulping. This process also saved money related to the expense of depleted vitality, lime consumed during causticizing process, and upkeep of the causticizing plant.
\end{abstract}

Keywords: Active alkali; Bagasse pulping; Conventional kraft; Green liquor; Physical strength properties

Contact information: a: Laboratory and Research, Misr Edfu Pulp Writing and Printing Paper Co. (MEPPCO), Aswan 81656, Egypt; b: Conservation Department, Faculty of Archaeology, Aswan University, Aswan 81528, Egypt; c: Restoration Department, High Institute of Tourism, Hotel Management and Restoration, Abukir, Alexandria 21526, Egypt; d: Forestry and Wood Technology Department, Faculty of Agriculture (EL-Shatby), Alexandria University, Alexandria 21545, Egypt; e: Chair of Climate Change, Environmental Development and Vegetation Cover, Department of Botany and Microbiology, College of Science, King Saud University, Riyadh 11451, Saudi Arabia; f: Timber Trees Research Department, Sabahia Horticulture Research Station, Horticulture Research Institute, Agriculture Research Center, Alexandria 21526, Egypt; *Corresponding authors: Mohamed Z.M. Salem (zidan_forest@yahoo.com); Asma A. Al-Huqail (aalhuqail@ksu.edu.sa)

\section{INTRODUCTION}

The increasing demand for papers has led to the search for alternative sources of fibers to be used in place of those from forestry trees. Cellulosic fibers for the pulp and paper industry can be obtained from non-wood materials depending on different raw materials such as flax plant, bamboo, reeds, sisal, papyrus, and agricultural residues (bagasse, cotton stakes, corn stakes, and maize stakes), as well as from wood branches and recycled paper (Jahan et al. 2006; Hosseinpour et al. 2010; Kumar et al. 2013; Gangwar et al. 2015; Moradbak et al. 2016a,b; Taha et al. 2019a, 2019b; Abo Elgat et al. 2020; Salem et al. 2020). 
Sugarcane (Saccharum officinarum L.) bagasse residue is a potentially promising raw material for papermaking; it is formed of 30\% sugarcane with 50\% fibers along with pith cells (El-Sakhawy 2005; Agnihotri et al. 2010). Pulp produced from bagasse has been reported as a potential alternative source to the pulp from wood to make a fiber with highly practical uses in the production of paper, board, and construction materials (Nyang au et al. 2019). To obtain less fines in the pulp of bagasse, the pre-extraction should be run. This approach was shown to improve the pulp drainage compared with non-extracted bagasse pulp (Jahan et al. 2009). Another technological method is to use oxygen as a pulp delignification agent in the soda- anthraquinone (AQ) method for reducing the kappa number 50\% with marginal yield loss (Mohta et al. 1998; Yue et al. 2016). Additionally, the brightness or strength properties of paper from bagasse soda-AQ pulp was improved under solid-state fermentation conditions (Agnihotri et al. 2012). Pulp yield, strength properties, and brightness were increased, which requires less chemicals in cooking and bleaching when increasing proper bagasse depithing (Dixit et al. 2014) and increasing the pulp additives (Ghazy et al. 2014).

The purpose of the chemical recovery process is to recover and regenerate the pulping chemicals, and to burn the organic material dissolved from bagasse to generate steam (Vakkilainen and Välimäki 2009). The chemical recovery process consists of an evaporation plant, recovery boiler, and causticizing plant. The object of the causticizing procedure is to change over the sodium carbonate $\left(\mathrm{Na}_{2} \mathrm{CO}_{3}\right)$ into the dynamic cooking concoction, sodium hydroxide, as productively as could be expected under the circumstances. The procedure can be partitioned into four sections: green liquor production/filtration, slaking, causticizing, and white liquor production/filtration. The smelt from the kettle is broken down in water and prepared into the green liquor in the dissolving tank (Um and Van Walsum 2010; Giglio 2018). The raw green liquor, consisting mostly of sodium carbonate and sodium sulfide, is pumped into the causticizing area. The green liquor is clarified and brought into contact with reburned lime. In the kraft process, the recovery efficiency for sodium was reported to be as high as 97\% (Tran and Vakkilainnen 2008).

Some problems can be caused by reburned lime during the processes of green liquor slaking, lime mud settling, and causticizing, where reburned lime should be soft as well as consist of pebbles (2-cm diameter) (Venkatesh 1992). In causticizing, the green liquor is converted into white liquor by converting sodium carbonate into sodium hydroxide, an active cooking chemical. The white liquor is produced by the separation of the lime mud $\left(\mathrm{CaCO}_{3}\right)$ as a by-product of causticizing (Nurmesniemi et al. 2007; Figueirêdo et al. 2012; Wang et al. 2012; Azgomi 2014; Mao et al. 2015). More recently, lime mud as a waste from paper mills has been utilized in many applications, such as to synthesize calcium hydroxide nanoparticles ( Vu et al. 2019), treatment of wastewater (Hartley et al. 2004), in the materials used for building, such as bricks and cements (Madrid et al. 2018), and agricultural soils (Bellaloui et al. 1999).

Black liquor, the by-product from the kraft process, contains lignin, degradation products of lignin, extractives, polysaccharides, and inorganic compounds (Gullichsen and Fogelholm 1999), and it has been studied from non-wood pulping wheat straw and sugarcane bagasse (Xu et al. 2006; Zhang et al. 2013). The characteristics of black liquor can be affected by changing the raw materials composition after pretreatment and pulping. Green liquor is an easily accessible and rich hydrosulfide and low hydroxide source in kraft mills compared with conventional kraft pulping (Sjöblom et al. 1993; Ban and Lucia 2005; Xie et al. 2013). 
To recycle and reuse the weak black liquor, an effective process for biomass sugar liberation was reported from deacetylation/dilute alkaline pretreatment followed by mechanical refining without severe chemical modification to lignin (Chen et al. 2018). In addition, Hubbe et al. (2019) reviewed the recovery of lignin from spent alkaline pulping liquors using acidification and membrane separation.

When only strength properties are needed and not high brightness, a wide range of lower levels of delignification can be reasonably considered, especially for reducing the consumption of bleached softwood pulp for production Writing and Printing Paper in Misr Edfu Pulp Writing and Printing Paper Company (MEPPCO). Therefore, the present report demonstrates the effect of green liquor pulping in bagasse by measuring changes in yield, reject, kappa number, brightness, and physical strength over conventional kraft pulping. Different charges of green liquor pulping parameters as active alkali charge, temperature, and time have been used in the current study to optimize the pulping process. The objective of this research is to reap the benefits of green liquor pulping with the lowest capital cost.

\section{EXPERIMENTAL}

\section{Materials}

Depithed bagasse

Depithed sugarcane bagasse (7\% of the pith removed by sieving) from the bulk storage of Misr-Edfu Pulp, Writing and Printing Paper Company (Edfu, Aswan, Egypt) of year 2019 was washed with water to remove extraneous dirt, sand, nodes, and other foreign materials. The washed material was air-dried, and then stored in polyethylene bags under dry conditions for experimental work.

\section{Chemical Reaction for Green Liquor}

The chemical reaction can be described as the following:

$$
\begin{aligned}
& \text { Green liquor }+ \text { lime }=\text { lime mud }+ \text { White liquor } \\
& \text { Sodium carbonate }+ \text { water }+ \text { calcium oxide }= \\
& \text { calcium carbonate }+ \text { sodium hydroxide }
\end{aligned}
$$

The major chemical compositions of green liquor are: sodium carbonate, sodium hydroxide, and sodium sulfide. Sodium sulfide, the major constituent of the smelt that helps to reduce the degradation of cell wall fiber of bagasse during pulping in the digester, was produced from the reduction of sodium sulfate in the recovery boiler.

Green liquor and cooking liquor (white liquor mixed with diluted black liquor) used in all of the experiments were obtained from the causticizing industrial kraft pulp mill (MEPPCO), and consisted of 21.08 and $44.64 \mathrm{~g} / \mathrm{L}$ sodium hydroxide, 19.84 and $9.92 \mathrm{~g} / \mathrm{L}$ $\mathrm{Na}_{2} \mathrm{~S}, 45.88$ and $9.92 \mathrm{~g} / \mathrm{L} \mathrm{Na}_{2} \mathrm{CO}_{3}$, and sulphidity of 22.85 and $18.18 \%$, respectively. All the concentrations are expressed as equivalents of $\mathrm{Na}_{2} \mathrm{O}$, which were analyzed by standard TAPPI test method TAPPI T624 os-68 (1968). The details of chemical composition of green and white liquor are given in Table 1. 
Table 1. The Major Chemical Composition of the Green and White Liquors Used in the Pulping Process

\begin{tabular}{|c|c|c|}
\hline Chemicals & $\begin{array}{l}\text { Green Liquor } \\
\text { (Value as } \mathrm{Na}_{2} \mathrm{O} \text { ) }\end{array}$ & $\begin{array}{c}\text { Conventional Kraft } \\
\text { White Liquor (Value as } \mathrm{Na}_{2} \mathrm{O} \text { ) }\end{array}$ \\
\hline Total titrated alkaline (TTA) & $86.80 \mathrm{~g} / \mathrm{L}$ as $\mathrm{Na}_{2} \mathrm{O}$ & $64.48 \mathrm{~g} / \mathrm{L}$ as $\mathrm{Na}_{2} \mathrm{O}$ \\
\hline Sodium hydroxide $(\mathrm{NaOH})$ & $21.08 \mathrm{~g} / \mathrm{L}$ as $\mathrm{Na}_{2} \mathrm{O}$ & $44.64 \mathrm{~g} / \mathrm{L}$ as $\mathrm{Na}_{2} \mathrm{O}$ \\
\hline Sodium sulfide ( $\left.\mathrm{Na}_{2} \mathrm{~S}\right)$ & $19.84 \mathrm{~g} / \mathrm{L}$ as $\mathrm{Na}_{2} \mathrm{O}$ & $9.92 \mathrm{~g} / \mathrm{L}$ as $\mathrm{Na}_{2} \mathrm{O}$ \\
\hline Active alkali (NaOH + Na2S), (TAA) & $41.02 \mathrm{~g} / \mathrm{L}$ as $\mathrm{Na}_{2} \mathrm{O}$ & $54.56 \mathrm{~g} / \mathrm{L}$ as $\mathrm{Na}_{2} \mathrm{O}$ \\
\hline Sodium carbonate $\left(\mathrm{Na}_{2} \mathrm{CO}_{3}\right)$ & $45.88 \mathrm{~g} / \mathrm{L}$ as $\mathrm{Na}_{2} \mathrm{O}$ & $9.92 \mathrm{~g} / \mathrm{L}$ as $\mathrm{Na}_{2} \mathrm{O}$ \\
\hline Sulphidity (\%) & 22.85 & 18.18 \\
\hline
\end{tabular}

\section{Chemical Characterizations of Bagasse}

Approximately $20 \mathrm{~g}$ of depithed bagasse (DPB) (Lois-Correa 2012; Lois and Suarez 1993), were ground into a powder in a Culatti micro impact mill type grinder (Model MFC, CZ13; ZENITH, Zurich, Germany) with a 1-mm screen, and fraction passing through 40mesh size but retained on+60-mesh size and used for chemical analysis. The chemical characterization of bagasse was conducted as per TAPPI standard test methods. The tests that were carried out included: cold and hot water solubility (TAPPI T207cm-08 (2008)), $1 \%$ sodium hydroxide solubility (TAPPI T212-om-02 (2002)), solvent extraction alcoholbenzene solubility $(1: 2 \mathrm{v} / \mathrm{v})$ (TAPPI T204cm-07 (2007)), acid-insoluble lignin (TAPPI T222om-15 (2015)), and pentosans (gravimetric method) as per TAPPI T19 wd-71 (1950). For $\alpha$-cellulose (gravimetric method), holocellulose, and ash content, the following methods were used TAPPI T203 cm-99 (1999), TAPPI T249-09 (2009), and TAPPI T211 om-16 (2016), respectively. Four samples were used for each chemical characterization.

\section{Pulping Process for the Depithed Bagasse}

All the DPB pulping experiments were conducted in a laboratory stainless steel pilot batch digester of 3-L capacity equipped with a rotating and heating oil bath, with controlling the temperature and pressure gauge. The capacity of digester used was $200 \mathrm{~g}$ based on oven dry weight of bagasse. It was cooked under different cooking conditions such as maximum temperature that ranged from 160 to $170{ }^{\circ} \mathrm{C}$, cooking time from 20 to 50 min, active alkali from10 to $13 \%$ (as $\mathrm{Na}_{2} \mathrm{O}$ ), and liquor to raw material ratio of $7: 1$. Pulping conditions, including liquor ratio, and sulphidity were maintained similar for all the experiments (Lindfors et al. 1989; Klarin-Henricson 2004; Hurter 2007).

At the end of the cooking, the bomb was removed and quenched in the water tank to depressurize. The digested material was dispersed with a pulp disintegrator (Model: CA 371; NORAM, Lorentzen Wettre, Viderögatan, Kista, Sweden) and washed with hot water to remove the black liquor and dissolved substances. After thorough washing of bagasse pulp (Fig. 1) was screened over a flat diaphragm screen (type: Valley Iron Work Corp., Appleton, WI, USA) with a 0.25 -mm slots.

\section{Physical, Chemical, and Mechanical Properties of Depithed Bagasse Pulp}

Pulps were evaluated for unscreened and screened yield, rejects content, kappa number, and brightness as per standard test procedures. Moisture content was determined as per TAPPI T210 cm-13 (2013).Kappa number of unbleached pulp, brightness of the pulp, and Freeness of pulp (Schopper Riegler, $\mathrm{SR}^{0}$ ) were determined as per standard methods of TAPPI T236 om-13 (1996), TAPPI T525 om-17 (2017), and ISO 5267-1 
(1999), respectively. Handsheets of $60 \mathrm{~g} / \mathrm{m}^{2}$ from bagasse pulp were made on a sheet former as per TAPPI test method TAPPI/ANSI T205 sp-18 (2018).
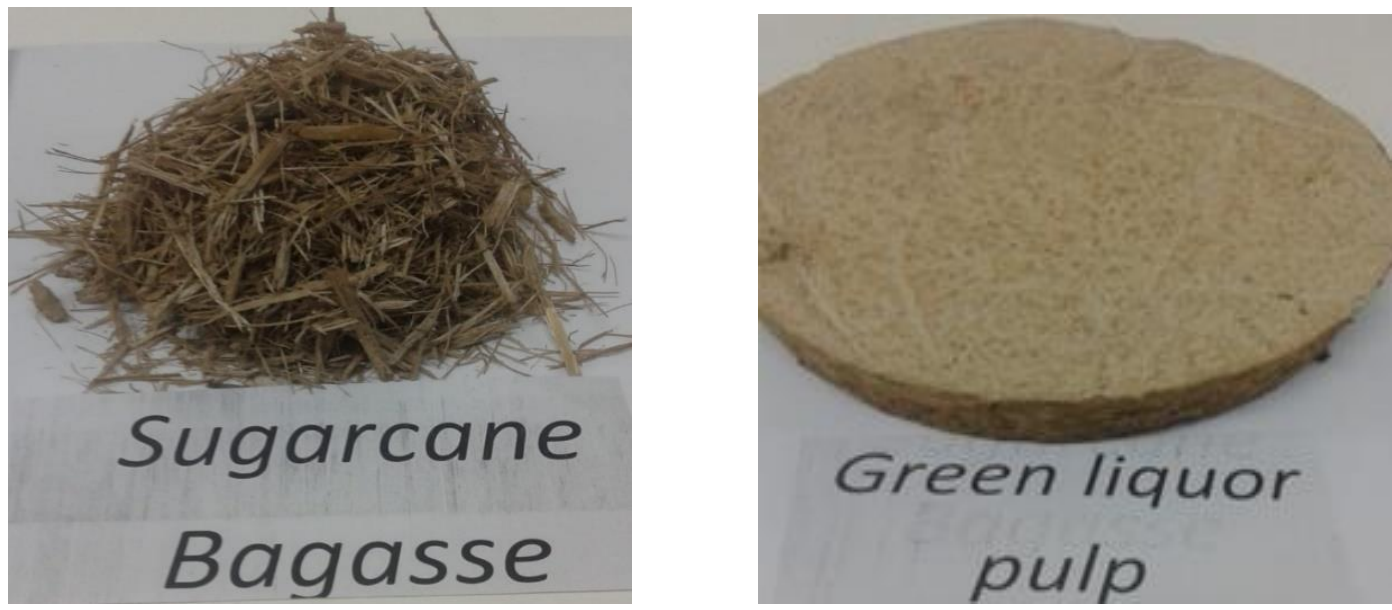

Fig. 1. Sugarcane bagasse and the green liquor pulp (optimum condition)
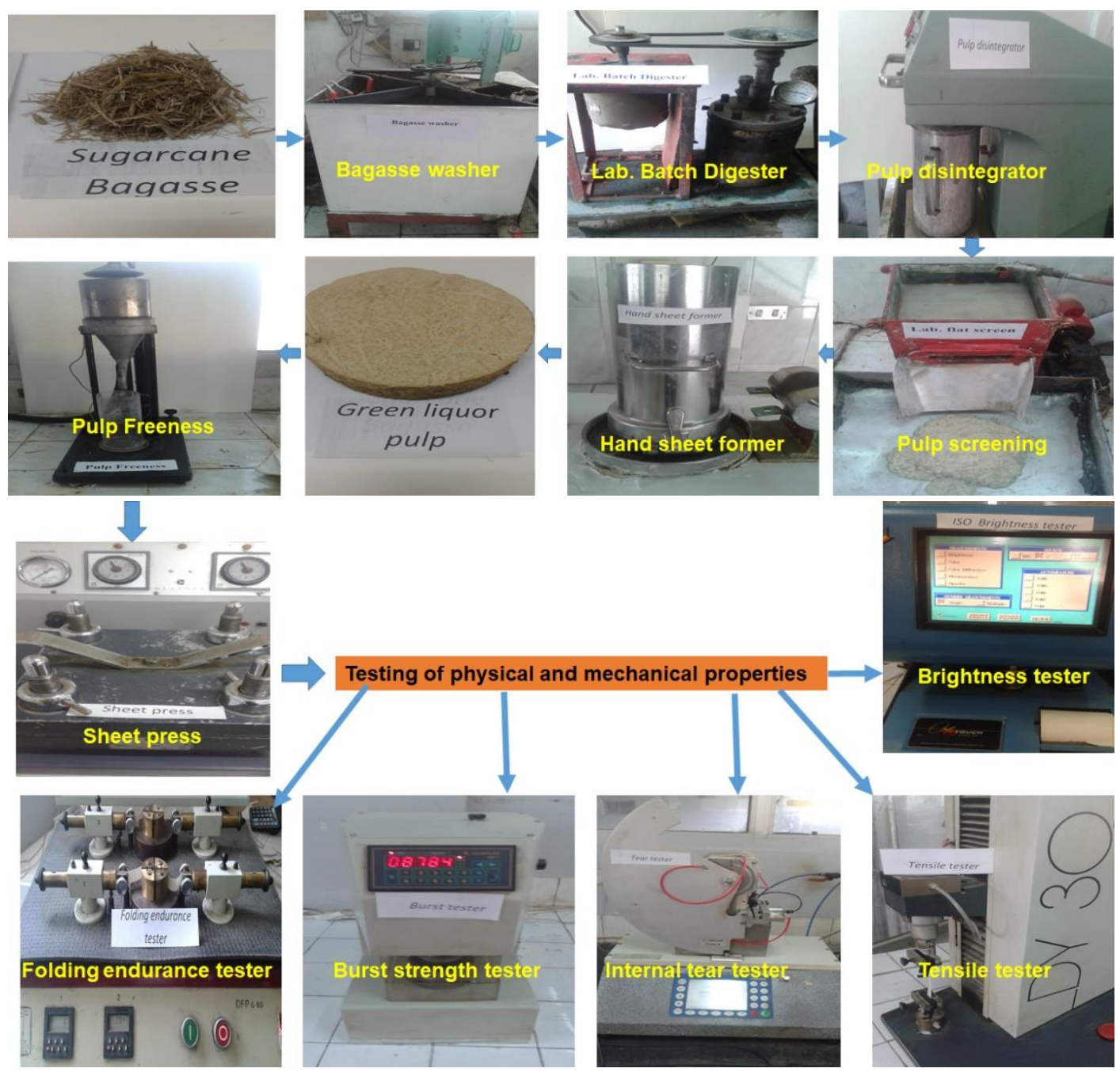

Fig. 2. Summary of the pulp experiment and measuring the mechanical, and physical properties of handsheets 
The physical strength properties of paper sheets made from the pulp of DPB were determined as per TAPPI T220 sp-16 (2016), tensile breaking strength as per TAPPI T404 wd-03 (2003), internal tearing resistance index as per TAPPI T414 om-12 (2012), burst strength as per TAPPI T403 om-15 (2015), and folding endurance tests (MIT; Massachusetts Institute of Technology) as per TAPPI T511 om-13 (2013). Figure 2 shows the laboratory production of DPB pulp and measuring the mechanical and physical properties of the produced hand sheets.

\section{Statistical Analysis}

Data for the mechanical and physical properties for each factor affecting the pulping processes of DPB were statistically analyzed in a one way analysis of variance (ANOVA) using the SAS system software (SAS Institute, version 2001, Cary, NC, USA). Comparisons among means were measured using the least significant difference (LSD) test at alpha $<0.05$.

\section{RESULTS AND DISCUSSION}

\section{Chemical Analysis of Depithed Bagasse}

The detailed results of chemical composition of depithed bagasse (DPB) are given in Table 2. These results were compared with and agreed with data existing in the literature. Pentosan content determination measures the total amount of pentose-based carbohydrate in a material. The pentosans content was $30.42 \%$, which was higher than the DPB (Agnihotri et al. 2010; Hamzeh et al. 2013) and some tropical hardwoods of Eucalyptus camaldulensis (14\%) and Meryta sinclairii (16\%) wood branches (Salem et al. 2020). Additionally, this amount in general is higher than in softwood (7 to 10\%) and hardwood species (19 to 25\%) (Sjöström 1993; El-Sakhawy 2005).

Table 2. Chemical Composition of Depithed Bagasse

\begin{tabular}{|c|c|c|c|}
\hline Chemical Parameters (\%) & $\begin{array}{c}\text { Present work Value } \\
(\%)\end{array}$ & \multicolumn{2}{|c|}{ Comparative results (\%) } \\
\cline { 3 - 4 } & $72.38 \pm 0.23$ & 73.7 & $\mathrm{DPB}^{\mathrm{a}}$ \\
\hline Holocellulose & $30.42 \pm 0.49$ & 13.7 & 71.03 \\
\hline Pentosan & $20.03 \pm 0.17$ & 27.7 & 21.7 \\
\hline Acid insoluble lignin & $5.68 \pm 0.27$ & $3.8^{*}$ & - \\
\hline Extractive (alcohol-benzene) & $38.22 \pm 0.22$ & 31.8 & 32.3 \\
\hline $\begin{array}{c}\text { Solubility on 1\% sodium } \\
\text { hydroxide }\end{array}$ & & & \\
\hline Solubility on hot water & $8.11 \pm 0.27$ & 6.5 & 7.42 \\
\hline Ash & $1.89 \pm 0.03$ & 4.8 & 2.1 \\
\hline
\end{tabular}

a: Data from Hamzeh et al. (2013); b: Data from Agnihotri et al. (2010); * based on ethanoldichloromethane mixture extraction

The acid insoluble lignin content was similar to that reported by Agnihotri et al. (2010) and Garg and Singh (2004), and lower than that reported by Hamzeh et al. (2013). The ash content was higher than that of the percentages reported based on oven dry (o.d) bagasse that ranged from $0.484 \%$ (coarse pulp) to $0.862 \%$ (benchmark pulp) (Rainey 2012), and lower than that reported from Hamzeh et al. (2013) and Agnihotri et al. (2010), and similar to that reported from Garg and Singh (2004). It was reported that the ash content of whole bagasse is $0.85 \%$, which is lower than the DPB $(1.17 \%)$ with $50 \%$. This could be 
attributed to the completed and continuous degradation for the whole bagasse (Pydimalla et al. 2019). Such lower ash content results in softness and easier possibilities in chemical recovery, where the presence of silica in agriculture residue is considered undesirable to form deposits on the internal surfaces of the evaporators during the black liquid evaporation process resulting from the fiber cooking process. These deposits preclude black liquid recovery processes.

\section{Effect of Parameters Condition on Yield, Kappa Number, Brightness, and Physical Strength}

Bagasse materials were cooked with and without green liquor at varying conditions, alkali charge from $10 \%$ to $13 \%$, varying times from 20 to $50 \mathrm{~min}$, and intervals at the following temperature from 160 to $170{ }^{\circ} \mathrm{C}$. Initially, the optimum values of conventional kraft pulping were evaluated at $11 \%$ (AA), $160{ }^{\circ} \mathrm{C}, 30 \mathrm{~min}$, and solid to liquor ratio of 7:1 (Lloyd et al. 1995). The results shown in Table 3 indicate that kappa number and rejects drop gradually with AA increase while screened pulp yield increased $2.6 \%$ at $11 \%$ AA. Additionally, the brightness improved 3\%, which was higher than conventional kraft pulping at similar conditions. At $13 \%$ AA, a sharp reduction in values of the rejects content, kappa number, and screened pulp yield values by $3 \%, 24.3 \%$, and $0.3 \%$, respectively, compared with green liquor pulping at $10 \%$ AA were reported; those results are in agreement with the literature (Lucia 2001; Singh et al. 2002).

Table 3. Evaluation of Physical, Chemical, and Mechanical Properties of Unbleached Bagasse (With and Without Green Liquor) Pulp with Variables Active Alkali Charge (AA) at Pulping Conditions (cooking temperature $160^{\circ} \mathrm{C}$, cooking time $30 \mathrm{~min}$, and solid to liquor ratio of 7:1)

\begin{tabular}{|c|c|c|c|c|c|}
\hline & & \multicolumn{3}{|c|}{ Pulping Method } & \\
\hline Parameter & $\begin{array}{c}\text { Conventional } \\
\text { Kraft }\end{array}$ & \multicolumn{3}{|c|}{ Green Liquor } & \\
\hline $\begin{array}{c}\text { Active alkali charge (AA) } \\
(\%)\end{array}$ & 11 & 10 & 11 & 13 & \\
\hline Unscreened pulp yield (\%) & 55.1 & 57.3 & 56.8 & 54 & \\
\hline Screened pulp yield (\%) & 52.5 & 53.1 & 55.1 & 52.8 & \\
\hline Rejects (\%) & 2.6 & 4.2 & 1.7 & 1.2 & \\
\hline Free alkali $(\mathrm{g} / \mathrm{L})$ as $\mathrm{Na}_{2} \mathrm{O}$ & 1.2 & 0.9 & 1.5 & 1.8 & \\
\hline Kappa number & 13 & 11.1 & 10 & 8.4 & \\
\hline Schopper Riegler (SR $\left.{ }^{0}\right)$ & 19 & 20 & 21 & 23 & \\
\hline \multicolumn{5}{|c|}{ Physical and Mechanical Properties* } & LSD $^{* *}$ \\
\hline Brightness (\% ISO) & $35^{c} \pm 1.1$ & $36^{c} \pm 0.3$ & $38^{b} \pm 0.8$ & $\begin{array}{l}41^{\mathrm{a}} \pm \\
0.7\end{array}$ & 1.46 \\
\hline Tensile index (N.m/g) & $52.5^{d} \pm 0.2$ & $\begin{array}{c}57.2^{\mathrm{c}} \pm \\
0.1\end{array}$ & $60^{b} \pm 0.8$ & $\begin{array}{l}62^{\mathrm{a}} \pm \\
0.4\end{array}$ & 0.86 \\
\hline Tear index $\left(\mathrm{mN} \cdot \mathrm{m}^{2} / \mathrm{g}\right)$ & $4.6 \pm 0.7$ & $5.3 \pm 0.8$ & $5 \pm 0.6$ & $\begin{array}{l}4.8 \pm \\
1.1\end{array}$ & ns \\
\hline Burst index $\left(\mathrm{kPa} \cdot \mathrm{m}^{2} / \mathrm{g}\right)$ & $4.4 \pm 0.6$ & $4.7 \pm 0.3$ & $4.8 \pm 0.3$ & $\begin{array}{c}4.8 \pm \\
0.4\end{array}$ & ns \\
\hline Double fold number & $26^{c} \pm 1$ & $25^{\mathrm{c}} \pm 1$ & $30^{b} \pm 1$ & $42^{a} \pm 1$ & 1.88 \\
\hline
\end{tabular}

Fares et al. (2020). "Green liquor for bagasse pulping," BioResources 15(4), 7458-7474. 7464 
Generally, physical strength is also improved with increasing alkali charge. Indeed, work by Svedman and Tikka (1998) has conclusively supported this latter finding, demonstrating white liquor savings of up to $20 \%$ for pretreatment work with wood chips. Additionally, the decreased alkali requirement in the subsequent kraft stage is probably due to the extraction and liberation of pulp hemicelluloses during green liquor pretreatment that normally tend to produce sugar acids via peeling reactions (Andrews et al. 1985). Additionally, it can be observed that from Table 3 that at the same pulping conditions for green liquor, pulping has highest values in physical and mechanical properties of handsheet pulp than conventional kraft pulping. At the same time, green liquor pulping can be used without operation the causticizing plant.

\section{Effect of Alkali Charge (AA)}

To further maximize the benefit of direct pulping by green liquor, pulping was completed at increasing AA, with a target to produce the best physical and mechanical properties compared to conventional kraft pulp. During pulping with green liquor at $11 \%$ (AA), the screened pulp yield was significantly improved $2.6 \%$, kappa number was reduced $23 \%$, rejects reduced $0.9 \%$, and brightness increased $3 \%$ compared to conventional kraft pulp. An increase in the active alkali to $13 \%$ led to limited improvements in the screened bagasse pulp yield (Lois-Correa et al. 2010). Screened pulp yield of Phragmites karka increased as doses of active alkali increased from 9 to $15 \%\left(\mathrm{as} \mathrm{Na}_{2} \mathrm{O}\right)$ then declined (Kumar et al. 2013). Other studies showed the increase of AA of white liquor charge led to easily collapsed fibers, producing more fiber-to-fiber bonding during papermaking (Feria et al. 2012), and allowing for easier beating with pulp softened by forming fibrous splits (Seth 2001).

Physical strength properties of unbleached DPB pulp were improved with increasing AA, such as tensile, tear, burst, and double-fold number indices, for green liquor pulp at $11 \%$ AA, compared to conventional kraft pulp, these properties increased 14.28, $8.69,9.09$, and $13.3 \%$, respectively. The improvement in physical strength properties specifically for tear and burst index was also reported by Höglund et al. (1994). Detailed results of optimization of variables of active alkali charge with green liquor pulping and conventional kraft pulping $v s$. screen yield, kappa number, rejects, brightness, and physical strength are given in Table 3. The amount of carbohydrate dissolved during the process of cooking depends on the alkalinity and effective alkali charge. With an increase in the alkali charge and cooking time, the rate of dissolution of bamboo fibers is accelerated (Moradbak et al. 2016a). The high percentages of unscreened pulp yield could be attributed to the presence of partially degraded fragments of lignin or to thermally unstable hemicelluloses (De Lemos et al. 2017).

\section{Effect of Cooking Temperature}

It can be seen that by increasing the cooking temperature from 160 to $165^{\circ} \mathrm{C}$ in green liquor pulping, the pulp properties and physical strength were enhanced compared with conventional kraft pulp. However, above $165^{\circ} \mathrm{C}$ and up to $170{ }^{\circ} \mathrm{C}$ an undesirable effect was shown in pulp properties, for example some reductions in screened pulp yield and kappa number by $4.5 \%$, and $43.8 \%$, respectively, were found and the brightness was also improved $4 \%$. Additionally, the physical strength showed improvements in tensile, burst, and double fold of $6.87 \%, 6.82 \%$, and $23.07 \%$, respectively, and slight reduction in tear by $4.54 \%$ (Gartside and Langfors 1981; Darwesh et al. 1998). 
Detailed results of the optimization of variables of cooking temperature with green liquor pulping and conventional kraft pulping vs. screen yield, kappa number, rejects, brightness, and physical strength are given in Table 4 . The results indicated that the screened pulp yield and kappa number dropped significantly from 160 to $170{ }^{\circ} \mathrm{C}$ in green liquor pulping, the brightness improved with increasing temperature, and slight reductions in physical strength were recorded at $170{ }^{\circ} \mathrm{C}$, especially with tear index.

Different temperatures of $160,165,170,175$, and $180{ }^{\circ} \mathrm{C}$ and cooking times of 0 , $30,60,90,120$, and 150 min strongly affected the depithed kraft pulping of Egyptian bagasse, where the temperature above $175{ }^{\circ} \mathrm{C}$ is non-selective for kraft pulping (Ghazy 2016). The degradation of polysaccharides was higher than lignin dissolution at the temperature $180{ }^{\circ} \mathrm{C}$ (Ghazy 2016).

Table 4. Evaluation of Physical, Chemical, and Mechanical Properties of Unbleached Bagasse (With and Without Green Liquor) Pulp With Variables Cooking Temperature at Pulping Conditions (Active Alkali Charge (AA) 11\%, Cooking Time $30 \mathrm{~min}$, and solid to Liquor Ratio 7:1)

\begin{tabular}{|c|c|c|c|c|c|}
\hline & & \multicolumn{3}{|c|}{ Pulping Method } & \\
\hline Parameter & $\begin{array}{c}\text { Conventional } \\
\text { Kraft }\end{array}$ & \multicolumn{3}{|c|}{ Green Liquor } & \\
\hline Cooking temperature $\left({ }^{\circ} \mathrm{C}\right)$ & 160 & 160 & 165 & 170 & \\
\hline Unscreened pulp yield (\%) & 55.1 & 56.8 & 54.5 & 48 & \\
\hline Screened pulp yield (\%) & 52.5 & 55.1 & 53.5 & 47.5 & \\
\hline Rejects (\%) & 2.6 & 1.7 & 1 & 0.5 & \\
\hline Free alkali $(\mathrm{g} / \mathrm{L})$ as $\mathrm{Na}_{2} \mathrm{O}$ & 1.2 & 1.5 & 1.1 & 0.6 & \\
\hline Kappa number & 13 & 10 & 8.5 & 7.3 & \\
\hline Schopper Riegler $\left(\mathrm{SR}^{0}\right)$ & 19 & 21 & 21 & 23 & \\
\hline \multicolumn{5}{|c|}{ Physical and Mechanical Properties* } & $\mathrm{LSD}^{\star \star}$ \\
\hline Brightness (\% ISO) & $35^{\mathrm{c}} \pm 1.2$ & $38^{b} \pm 0.3$ & $40^{\mathrm{a}} \pm 1$ & $39^{\mathrm{ab}} \pm 1$ & 1.76 \\
\hline Tensile index (N.m/g) & $52.5^{c} \pm 0.8$ & $60^{a} \pm 0.6$ & $51^{d} \pm 1$ & $56^{b} \pm 0.3$ & 1.36 \\
\hline Tear index $\left(\mathrm{mN} \cdot \mathrm{m}^{2} / \mathrm{g}\right)$ & $4.6 \pm 0.4$ & $5 \pm 1$ & $4.5 \pm 0.5$ & $4.2 \pm 0.5$ & ns \\
\hline Burst index $\left(\mathrm{kPa} \cdot \mathrm{m}^{2} / \mathrm{g}\right)$ & $4.4 \pm 0.7$ & $4.8 \pm 0.3$ & $4.8 \pm 0.4$ & $4.7 \pm 0.2$ & ns \\
\hline Double fold number & $26^{c} \pm 0.2$ & $30^{b} \pm 1$ & $31^{\mathrm{ab}} \pm 1$ & $32^{a} \pm 1$ & 1.64 \\
\hline
\end{tabular}

Recently, the handsheets made from whole bagasse pulp produced at $165{ }^{\circ} \mathrm{C}$ were found to be stiffer with higher tensile strength index values compared to sheets from depithed bagasse pulp (Pydimalla et al. 2019). The characteristic values of the pulp and black liquor of depithed bagasse processed for $1 \mathrm{~h}$ at $165^{\circ} \mathrm{C}$ have been promised and encouraged for papermaking (Pydimalla et al. 2019).

\section{Effect of Cooking Time}

To optimize the green liquor pulping of bagasse as affected by cooking time compared to conventional kraft pulping, the pulp was cooked for 20,30, and $50 \mathrm{~min}$, and other parameters were kept constant. A cooking time of 50 min has an undesirable effect, especially in screened pulp yield, which decreased $4.7 \%$. In contrast, kappa number and brightness were improved $37.7 \%$ and $8 \%$, respectively, compared to conventional kraft pulping (Mao and Hartler 1992; Klevinska and Treimanis 1997; Garg and Singh 2004). The physical strength was improved at 50 min cooking time, and the tensile, tear, burst, 
and double fold increased 4.96\%, 4.34\%, 20.4\%, and 30.7\%, respectively (Gartside and Langfors 1981).

Generally, the experimented cooking time at $30 \mathrm{~min}$ resulted in higher screened pulp yield by $2.6 \%$, lower kappa number by $23.08 \%$, and lower rejects by $0.9 \%$, compared with conventional kraft pulping at similar pulping conditions. Additionally, the mechanical strength properties were improved at 30 min cooking time compared to conventional kraft pulp at 30 min cooking time, for example the following increased, tensile index by $14.9 \%$, tear index by $8.7 \%$, burst index by $9.1 \%$, and double fold number by $15.4 \%$ (Rao 1997; Hurter 2007).

Table 5. Evaluation of Physical, Chemical, and Mechanical Properties of Unbleached Bagasse (With and Without Green Liquor) Pulp with Variables Cooking Time at Pulping Conditions (Active Alkali Charge (AA) 11\%, Cooking Temperature $160^{\circ} \mathrm{C}$, and solid to Liquor Ratio $7: 1$ )

\begin{tabular}{|c|c|c|c|c|c|}
\hline \multirow[t]{2}{*}{ Parameter } & & \multicolumn{3}{|c|}{ Pulping Method } & \\
\hline & Conventional & \multicolumn{3}{|c|}{ Green Liquor } & \\
\hline Cooking time(min) & 30 & 20 & 30 & 50 & \\
\hline Unscreened pulp yield (\%) & 55.1 & 56.6 & 56.8 & 49 & \\
\hline Screened pulp yield (\%) & 52.5 & 52.8 & 55.1 & 47.8 & \\
\hline Rejects (\%) & 2.6 & 3.8 & 1.7 & 1.2 & \\
\hline Free alkali $(\mathrm{g} / \mathrm{L})$ as $\mathrm{Na}_{2} \mathrm{O}$ & 1.2 & 1.5 & 1.5 & 0.8 & \\
\hline Kappa number & 13 & 14.8 & 10 & 8.1 & \\
\hline Schopper Riegler $\left(\mathrm{SR}^{0}\right)$ & 19 & 17 & 21 & 21 & \\
\hline \multicolumn{5}{|c|}{ Physical and Mechanical Properties* } & $\mathrm{LSD}^{\star \star}$ \\
\hline Brightness (\% ISO) & $35^{c} \pm 0.7$ & $32^{d} \pm 1$ & $38^{\mathrm{b}} \pm 1$ & $43^{a} \pm 1$ & 1.75 \\
\hline Tensile index (N.m/g) & $52.23^{c} \pm 0.9$ & $49^{d} \pm 0.5$ & $60^{\mathrm{a}} \pm 1$ & $55^{b} \pm 0.5$ & 1.44 \\
\hline Tear index $\left(\mathrm{mN} \cdot \mathrm{m}^{2} / \mathrm{g}\right)$ & $4.6 \pm 0.4$ & $5.1 \pm 0.4$ & $5 \pm 0.5$ & $4.8 \pm 0.2$ & ns \\
\hline Burst index $\left(\mathrm{kPa} \cdot \mathrm{m}^{2} / \mathrm{g}\right)$ & $4.4^{\mathrm{b}} \pm 0.4$ & $4.3^{b} \pm 0.7$ & $4.8^{\mathrm{ab}} \pm 0.3$ & $5.3^{a} \pm 0.2$ & 0.83 \\
\hline Double fold number & $26^{c} \pm 0.7$ & $20^{\mathrm{d}} \pm 0.4$ & $30^{\mathrm{b}} \pm 1$ & $34^{\mathrm{a}} \pm 1$ & 1.53 \\
\hline
\end{tabular}

${ }^{*}$ Means with the same letter(s) within the same row are significantly difference at 0.05 level probability; ** LSD: least significance difference; ns: not significant at 0.05 level of probability

Table 5 shows that the effect increasing cooking time, which indicated that the screened pulp yield and kappa number dropped significantly, especially at $50 \mathrm{~min}$. The most suitable time (30 min) resulted in maximum pulp yield, which allowed optimum separation of fibers from depithed sugarcane bagasse.

Brightness values also were improved with the green liquor pulping at different cooking times. Similar studies employing green liquor pulping of wood chips have shown that yield increases of $2 \%$ are possible, but longer times and higher temperatures were used to obtain these yields (Klevinska and Treimanis 1997; Lopez et al. 1999; Giglio 2018). In fact, using green liquor in pulping may help determine the precise role of carbonate in pulping reactions.

However, with all the studied permeates in the present study, the burst indices of green pulp were higher than as reported from a conventional bagasse pulp (Paul and Kasiviswanathan 1998) where the value was $3.6 \mathrm{kPa} \cdot \mathrm{m}^{2} / \mathrm{g}$. The green pulp bagasse pulp had tear strength lower than from the literature values for bagasse pulp produced from conventional process, where the values ranged from 5.5 to $6.1 \mathrm{mN} \cdot \mathrm{m}^{2} / \mathrm{g}$ (Sjöström 1993).

Furthermore, from the above results the following improvements were obtained at optimization conditions: screen pulp yield improved $2.6 \%$, rejects content reduced $0.9 \%$, 
kappa number reduced $26.9 \%$, brightness improved 3\%, tensile index improved $14.3 \%$, tear index improved $8.7 \%$, burst index improved $4.6 \%$, and double-fold number improved $15.4 \%$.

Finally, the results indicated that the pulping bagasse with and without green liquor in mild conditions (active alkali, temperature, and time) can significantly enhance pulp properties and strength. Moreover, reducing the energy required for pulping could be achieved. The benefits of the green liquor pulping not only include pulp yield and strength savings, but significant energy savings, lime consumed in the causticizing process, and maintenance of the causticizing plant.

\section{CONCLUSIONS}

1. In this study, the depithed bagasse were produced with industrial green liquor and white liquor (conventional kraft) at varying active alkali charge (AA) concentrations, temperatures, and time intervals.

2. Results indicate that optimum parameters suitable to produce pulp with green liquor pulping are $11 \% \mathrm{AA}, 160{ }^{\circ} \mathrm{C}$ cooking temperature, and 30 min cooking time. This gave the following physical and mechanical properties: unscreened pulp yield (56.8\%), screened pulp yield $(55.1 \%)$, rejects $(1.7 \%)$, free alkali as $\mathrm{Na}_{2} \mathrm{O}(1.5 \mathrm{~g} / \mathrm{L})$, kappa number (10), brightness (38 \% ISO), Schopper Riegler (SR 21$)$, tensile index (60 N.m/g), tear index $\left(5.0 \mathrm{mN} \cdot \mathrm{m}^{2} / \mathrm{g}\right)$, and burst index $\left(4.8 \mathrm{kPa} \cdot \mathrm{m}^{2} / \mathrm{g}\right)$.

3. Enhancing in physical and mechanical properties of handsheet pulp from green liquor than conventional kraft pulping was reported. Additionally, residual alkali in black liquor after pulping with green liquor was more than conventional kraft pulping at the same condition, so we can reduce the chemicals consumption during pulping process and saving the money.

4. Getting a clean environment due to dispensing of running the causticizing plant, which causes environmental damage due to the escalation of gases and dust resulting from the process of causticizing processes.

5. This, in addition to saving the cost of exhausted energy, lime, and maintenance of the causticizing plant, the results proved the successful use of the green liquor for bagasse pulping on an industrial scale.

\section{ACKNOWLEDGMENTS}

The authors are grateful to the Deanship of Scientific Research, King Saud University, for funding through the Vice Deanship of Scientific Research Chairs. 


\section{REFERENCES CITED}

Abo Elgat, W. A., Taha, A. S., Böhm, M., Vejmelková, E., Mohamed, W. S., Fares, Y. G., and Salem, M. Z. M. (2020). "Evaluation of the mechanical, physical, and antifungal properties of flax laboratory papersheets with the nanoparticles treatment," Materials 13(2), Article number 363.DOI: 10.3390/ma13020363

Agnihotri, S., Dutt, D., and Tyagi, C. H. (2010). "Complete characterization of bagasse of early species of Saccharum officinerum-Co 89003 for pulp and paper making," BioResources 5(2), 1197-1214.

Agnihotri, S., Dutt, D., and Vidyarthi, A. K. (2012). "ECF and TCF bleaching of Saccharum officinerum-co89003 bagasse soda-AQ pulp with alkali-thermo-tolerant crude xylanase from Coprinellus disseminatus sw-1 NTCC1165," BioResources 7(4), 5247-5257. DOI: 10.15376/biores.7.4.5247-5257

Andrews, E. K., Chang, H. M., and Eckert, R. C. (1985). "Extended delignification kraft pulping of softwoods-effect of treatments on chips and pulp with sulfide-containing liquors," Journal of Wood Chemistry and Technology 5(4), 431-450.DOI: 10.1080/02773818508085205

Azgomi, F. (2014). Impact of Liming Ratio on Lime Mud Settling and Filterability in the Kraft Recovery Process, Ph.D. Thesis, University of Toronto, Toronto, Canada.

Ban, W., and Lucia, L. A. (2005). "Kinetic profiling of green liquor-modified kraft pulping," Industrial \& Engineering Chemistry Research 44(9), 2948-2954. DOI: 10.1021/ie048762g

Bellaloui, A., Chtaini, A., Ballivy, G., and Narasiah, S. (1999). "Laboratory investigation of the control of acid mine drainage using alkaline paper mill waste," Water, Air, and Soil Pollution 111(1-4), 57-73. DOI: 10.1023/A:1005017912012

Chen, X., Kuhn, E., Nagle, N., Nelson, R., Tao, L., Crawford, N., and Tucker, M. (2018). "Recycling of dilute deacetylation black liquor to enable efficient recovery and reuse of spent chemicals and biomass pretreatment waste," Frontiers in Energy Research 6, Article 51. DOI: 10.3389/fenrg.2018.00051

Darwesh, H. R., Sharma, M., and Khan, P. A. (1998). "An experience with pandia continuous digester on agricultural residues," IPPTA 10, 67-74.

De Lemos, A. L., Mauss, C. J., and Santana, R. C. (2017). "Characterization of natural fibers: Wood, sugarcane and babassu for use in biocomposites," Cellulose Chemistry and Technology 51(7-8), 711-718.

Dixit, A. K., Dixit, T., Sharma, A., and Jain, R. K. (2014). "Efficient depithing of bagasse for reduction of water requirement in pulp mill," International Journal of Engineering Research \& Technology, ETWQQM-2014 Conference Proceedings 3(3), 1-4.

El-Sakhawy, M. (2005). "Effect of bleaching sequence on paper ageing," Polymer Degradation and Stability 87(3), 419-23. DOI:

10.1016/j.polymdegradstab.2004.10.002

Feria, M. J., García, J. C., Pérez, A., Gomide, J. L., Colodette, J. L., and López, F. (2012). "Process optimization in kraft pulping, bleaching, and beating of Leucaena diversifolia," BioResources 7(1), 0283-0297. DOI: 10.15376/biores.7.1.0283-0297

Figueirêdo, L. S., Costa, A. O. S., and Costa, Jr., E. F. (2012). "Semi empirical modeling of the stationary state of a real causticizing system in a pulp mill," Latin American Applied Research 42(3), 319-326.

Garg, M., and Singh, S. P. (2004). "Recycling potential of bagasse and wheat straw pulps," TAPPI Journal 3(9), 25-31. 
Gartside, G., and Langfors, N. G. (1981). "Developing the potential of Australian bagasse as a paper resource," in: Proceedings of the 1981 Conference of the Australian Society of Sugar Cane Technologists, Bundaberg, Queensland, Australia, pp. 233238.

Gangwar, A. K., Prakash, N. T., and Prakash, R. (2015). "Amenability of acacia and eucalyptus hardwood pulps to elemental chlorine-free bleaching: Application and efficacy of microbial xylanase," BioResources 10(4), 8405-8413.DOI: 10.15376/biores.10.4.8405-8413

Ghazy, M. B. M. (2016). "Effect of temperature and time on the kraft pulping of Egyptian bagasse," International Journal of Science and Research 5(2), 179-184.

Ghazy, M. B., Thabet, M. S., Abdel-Hai, F., and Owda, M. E. (2014). "Modification of Egyptian bagasse kraft pulping using yield-increasing additives. I - Effect on chemical properties," Egyptian Journal of Chemistry 57(5-6), 447-462.

Gullichsen, J., and Fogelholm, C. J. (1999). Chemical Pulping, $2^{\text {nd }}$ Ed., TAPPI Press, Helsinki, Finland.

Hamzeh, Y., Ashori, A., Khorasani, Z., Abdulkhani, A., and Abyaz, A. (2013). "Preextraction of hemicelluloses from bagasse fibers: Effects of dry-strength additives on paper properties," Industrial Crops and Products 43, 365-371. DOI:

10.1016/j.indcrop.2012.07.047

Hartley, W., Edwards, R., and Lepp, N. W. (2004). "Arsenic and heavy metal mobility in iron oxide-amended contaminated soils as evaluated by short-and long-term leaching tests," Environmental Pollution 131(3), 495-504.DOI: 10.1016/j.envpol.2004.02.017

Hosseinpour, R., Fatehi, P., Latibari, A. J., Ni, Y., and Sepiddehdam, S. J. (2010). "Canola straw chemimechanical pulping for pulp and paper production," Bioresource Technology 101(11), 4193-4197. DOI: 10.1016/j.biortech.2010.01.055

Höglund, O., Lehtonen, K. P., and Hjort, A. (1994). "Kraft pulping with black liquor pretreatment," in: Proceedings of Pulping Conference, Atlanta, GA, USA, pp. 12251225.

Hubbe, M. A., Alén, R., Paleologou, M., Kannangara, M., and Kihlman, J. (2019). "Lignin recovery from spent alkaline pulping liquors using acidification, membrane separation, and related processing steps: A review," BioResources 14(1), 2300-2351.

Hurter, R. W. (2007). "Developments in pulp and paper manufacture from sugarcane bagasse: Symposium and workshop," Queensland University of Technology, Brisbane, Australia.

ISO 5267-1 (1999). "Pulps — Determination of drainability — Part 1: Schopper-Riegler method,'International Standardization of Organization, Geneva, Switzerland.

Jahan, M. S., Saeed, A., Ni, Y., and He, Z. (2009). "Pre-extraction and its impact on the alkaline pulping of bagasse," Journal of Biobased Materials and Bioenergy 3(4), 380385. DOI:10.1166/jbmb.2009.1053

Jahan, M. S., Chowdhury, D. N., Russel, M. A. N., Mun, S. P., and Quaiyyum, M. A. (2006). "Alkaline sulfite-anthraquinone-methanol (ASAM) pulping of corn stalks," Cellulose Chemistry and Technology 40(7), 531-536.

Klarin-Henricson, A. (2004). "Organic sulphur reactions in black liquor at high evaporation temperatures and their practical importance,"Nordic Pulp \& Paper Research Journal 19(2), 245-249. DOI: 10.3183/NPPRJ-2004-19-02-p245-249

Klevinska, V., and Treimanis, A. (1997). "Pretreatment of wood chips with green liquor and its effect upon kraft delignification," Cellulose Chemistry and Technology 31(34), 253-261. 
Kumar, L., Dutt, D., and Bharti, A. (2013). "Delignification of Phragmites karka-A wetland grass-by soda pulping process," BioResources 8(3), 3426-3437. DOI: 10.15376/biores.8.3.3426-3437

Lindfors, E. L., Gellerstedt, G., Teder, A., and Tormund, D. (1989). "The distribution of different sulfur compounds in kraft cooking, in: International Symposium on Wood and Pulping Chemistry, Paris, France, pp. 167-170.

Lloyd, J. A., Allison, R. W., and Wrathall, S. H. (1995). "MCC [modified continuous cooking] pulping with additives and modified sulfidity profiles," Appita Journal 48(4), 284-287.

Lois-Correa, J., Flores-Vela, A., Ortega-Grimaldo, D., and Berman-Delgado, J. (2010). "Experimental evaluation of sugar cane bagasse storage in bales system," Journal of Applied Research and Technology 8(3), 365-375. DOI: 10.22201/icat.16656423.2010.8.03.460

Lois-Correa, J. A. (2012). "Depithers for efficient preparation of sugar cane bagasse fibers in pulp and paper industry," Ingeniería Investigación y Tecnología 13(4), 417424.

Lopez, I., Chang, H.-M., Jameel, H., and Wizani, W. (1999). "Effect of sodium sulfide pretreatment on kraft pulping," in: Proceedings of the 1999 TAPPI Pulping Conference, Atlanta, GA, USA, pp. 135.

Lucia, L. A. (2001). Novel Pulping Technology; Direct Green Liquor Utilization (DGLU) Pulping (Final Report: U.S. DOE Contract No.: DE-FC36-01GO10626), Institute of Paper Science and Technology, Georgia Institute of Technology, Atlanta, GA, USA.

Madrid, M., Orbe, A., Carré, H., and García, Y. (2018). "Thermal performance of sawdust and lime-mud concrete masonry units," Construction and Building Materials 169, 113-123. DOI: 10.1016/j.conbuildmat.2018.02.193

Mao, X., Ren, W., and Tran, H. (2015). "Measurement of free lime content in lime mud," TAPPI Journal 14(7), 481-489.

Mao, B., and Hartler, N. (1992). "Improved modified kraft cooking, 2: Modified cooking using high initial sulfide concentration," Nordic Pulp \& Paper Research Journal 7(4), 168-173. DOI: 10.3183/npprj-1992-07-04-p168-173

Mohta, D., Upadhyaya, J. S., Kapoor, S. K., Ray, A. K., and Roy, D. N. (1998). “Oxygen delignification of soda and soda-AQ bagasse pulps," TAPPI Journal 81(6), 184-187.

Moradbak, A., Tahir, P. M., Mohamed, A.Z., and Halis, R. B. (2016a). "Alkaline sulfite anthraquinone and methanol pulping of bamboo (Gigantochloa scortechinii)," BioResources 11(1), 235-248.DOI: 10.15376/biores.11.1.235-248

Moradbak, A., Tahir, P. M., Mohamed, A. Z., Peng, L. C., and Halis, R. (2016b). "Effects of alkaline sulfite anthraquinone and methanol pulping conditions on the mechanical and optical paper properties of bamboo (Gigantochloa scortechinii)," BioResources 11(3), 5994-6005.DOI: 10.15376/biores.11.3.5994-6005

Nurmesniemi, H., Pöykiö, R., and Keiski, R. L. (2007). “A case study of waste management at the Northern Finnish pulp and paper mill complex of Stora Enso Veitsiluoto Mills," Waste Management 27(12), 1939-1948.DOI: 10.1016/j.wasman.2006.07.017

Nyang`au, M. G., Muumbo, A. M., and Ondieki,C. M. M. (2019). "Production of particle boards from sugarcane bagasse and euphorbia sap," International Journal of Composite Materials 9(1), 1-6. DOI:10.5923/j.cmaterials.20190901.01 
Paul, S. K., and Kasiviswanathan, K. S. (1998). "Influence of pith on bagasse pulp, paper and black liquor properties," IPPTA 10, 1-8.

Pydimalla, M., Muthyala, B. R., and Adusumalli, R. B. (2019). "Influence of temperature on kraft pulping of whole bagasse and depithed bagasse," Sugar Tech 21(6), 1003-

1015.DOI: $10.1007 / \mathrm{s} 12355-019-00719-8$

Rainey, T. J. (2012). "A comparison between highly depithed and conventionally depithed bagasse pulp," APPITA J. 65(2), 178-183.

Rao, M. (1997). Industrial Utilization of Sugar Cane and Its Coproducts, ISPCK Publishers and Distributors, New Delhi, India.

Salem, M. Z. M., Abo Elgat, W. A. A., Taha, A. S., Fares, Y. G., and Ali, H. M. (2020). "Impact of three natural oily extracts as pulp additives on the mechanical, optical, and antifungal properties of paper sheets made from Eucalyptus camaldulensis and Meryta sinclairii wood branches," Materials 13(6), Article number 1292. DOI: $10.3390 / \mathrm{ma13061292}$

Seth, R. S. (2001). "The difference between never-dried and dried chemical pulps," Solutions! (Norcross, Ga) 1(1), 1-23.

Singh, J., Ragauskas, A. J., and Lucia, L. A. (2002). "Green liquor chip pretreatment as a feasible method for the enhancement of softwood pulp chemical properties," Cellulose Chemistry and Technology 36(1-2), 173-181.

Sjöblom, K., Mjoberg, J., and Hartler, N. (1983). "Extended delignification in kraft cooking through improved selectivity. Part 1. The effects of the inorganic composition of the cooking liquor," Paperi Ja Puu [Paper and Timber] 65(4), 227-240.

Sjöström, E. (1993). Wood Chemistry: Fundamentals and Applications, $2^{\text {nd }}$ Ed., Academic Press, San Diego, CA, USA.

Svedman, M., and Tikka, P. (1998). "The use of green liquor and its derivatives in improving kraft pulping," TAPPI Journal 10, 151-158.

Taha, A. S., Elgat, W. A. A., Salem, M. Z. M., Ali, H. M., Fares, Y. G., and Elshikh, M. S. (2019a). "Impact of some plant source additives on enhancing the properties and antifungal activities of pulp made from linen fibers," BioResources 14(3), 60256046.DOI: 10.15376/biores.14.3.6025-6046

Taha, A. S., Salem, M. Z. M., Abo Elgat, W. A. A., Ali, H. M., Hatamleh, A. A., and Abdel-Salam, E. M. (2019b). "Assessment of the impact of different treatments on the technological and antifungal properties of papyrus (Cyperus papyrus L.) sheets," Materials 12(4), Article number 620.DOI: 10.3390/ma12040620

TAPPI T203 cm-99 (1999). "Alpha-, Beta-, and Gamma-cellulose in pulp," TAPPI Press, Atlanta, GA, USA.

TAPPI T204-cm-07 (2007). "Solvent extractives of wood and pulp," TAPPI Press, Atlanta, GA, USA.

TAPPI T205 sp-18 (2018). "Forming hand sheets for physical tests of pulp," TAPPI Press, Atlanta, GA, USA.

TAPPI T207-cm-08 (2008). "Water solubility of wood and pulp," TAPPI Press, Atlanta, GA, USA.

TAPPI T210 cm-13 (2013). "Sampling and testing wood pulp shipments for moisture," TAPPI Press, Atlanta, GA, USA.

TAPPI T211 om-16 (2016). "Ash in wood, pulp, paper and paperboard: Combustion at 525 degrees C," TAPPI Press, Atlanta, GA, USA.

TAPPI T212-om-02 (2002). "One percent sodium hydroxide solubility of wood and pulps," TAPPI Press, Atlanta, GA, USA. 
TAPPI T220 sp-16 (2016). "Physical testing of pulp hand sheets," TAPPI Press, Atlanta, GA, USA.

TAPPI T222 om-15 (2015). “Acid-insoluble lignin in wood and pulp,” TAPPI Press, Atlanta, GA, USA.

TAPPI T19 wd-71 (T19 m-50-combined with T223) (1950). "Pentosans in wood," TAPPI Press, Atlanta, GA, USA.

TAPPI T236 cm-85 (1996). “Kappa number of wood,” TAPPI Press, Atlanta, GA, USA.

TAPPI T249 cm-09 (2009). "Carbohydrate composition of extractive-free wood and wood pulp by gas-liquid chromatography," TAPPI Press, Atlanta, GA, USA.

TAPPI T403-om-15 (2015). “Bursting strength of paper,” TAPPI Press, Atlanta, GA, USA.

TAPPI T404 wd-03 (2003). "Tensile strength tests of paper and paperboard," TAPPI Press, Atlanta, GA, USA.

TAPPI T414-om-12 (2012). "Internal tearing resistance of paper," TAPPI Press, Atlanta, GA, USA.

TAPPI T 511 om-13 (2013). "Folding endurance of paper (MIT tester)," TAPPI Press, Atlanta, GA, USA.

TAPPI T525 om-17 (2017). "Diffuse brightness of paper, paperboard and pulp (d/0)," TAPPI Press, Atlanta, GA, USA.

TAPPI T624 os-68 (1968). "Analysis of soda and sulfate white and green liquors," TAPPI Press, Atlanta, GA, USA.

Tran, H., and Vakkilainnen, E. K. (2008). The Kraft Chemical Recovery Process. TAPPI Press. Available online at: http://www.tappi.org/content/events/08kros/manuscripts/1-1.pdf [Accessed].

Um, B. H., and Van Walsum, G. P. (2010). "Mass balance on green liquor pre-pulping extraction of northeast mixed hardwood," Bioresource Technology 101(15), 59785987.DOI: 10.1016/j.biortech.2010.03.004

Vakkilainen, E., and Välimäki, E. (2009). "Effect of lignin separation to black liquor and recovery boiler operation," in: TAPPI Engineering, Pulping \& Environmental Conference, Memphis, TN, USA, pp. 1515-1556.

Venkatesh, V. (1992). "Lime reburning: The rotary lime kiln," in: Chemical Recovery in the Alkaline Pulping Processes, TAPPI Press, Atlanta, GA, USA, pp. 153-179.

Vu, H. H., Khan, M. D., Chilakala, R., Lai, T. Q., Thenepalli, T., Ahn, J. W., Park, D. U., and Kim, J. (2019). "Utilization of lime mud waste from paper mills for efficient phosphorus removal," Sustainability 11(6), Article number 1524.DOI:10.3390/su11061524

Wang, J., Wei, P., Liu, P., and Sun, W. (2012). "Identifying appropriate conditions for producing spindle-like causticizing precipitated calcium carbonate for paper filler applications," BioResources 7(4), 5894-5903. DOI: 10.15376/biores.7.4.5894-5903

Xie, Z. H., Zhou, J. H., Li, H. M., and Sun, G. W. (2013). "Comparison between green liquor pretreatment-kraft pulping and conventional kraft pulping," Advanced Materials Research 781-784, 2650-2653. DOI: 10.4028/www.scientific.net/AMR.781-784.2650

Xu, F., Sun, J. X., Sun, R., Fowler, P., and Baird, M. S. (2006). "Comparative study of organosolv lignins from wheat straw," Industrial Crops and Products 23(2), 180-193. DOI: 10.1016/j.indcrop.2005.05.008

Yue, F., Chen, K. L., and Lu, F. (2016). "Low temperature soda-oxygen pulping of bagasse," Molecules 21(1), Article number 85. DOI: 10.3390/molecules21010085 
Zhang, A. P., Liu, C. F., Sun, R. C., and Xie, J. (2013). "Extraction, purification, and characterization of lignin fractions from sugarcane bagasse," BioResources $8(2)$, 1604-1614. DOI: 10.15376/biores.8.2.1604-1614

Article submitted: May 30, 2020; Peer review completed: July 25, 2020; Revised version received and accepted: July 27, 2020; Published: August 10, 2020.

DOI: 10.15376/biores. 15.4.7458-7474 